九州大学学術情報リポジトリ

Kyushu University Institutional Repository

\title{
Internode Elongation under Different Rising Water Conditions in African Floating Rice (Oryza glaberrima Steud.)
}

Watarai, Maki

Laboratory of Crop Science, Faculty of Agriculture, Kyushu University

Inouye, Jun

Laboratory of Crop Science, Faculty of Agriculture, Kyushu University

https://doi.org/10.5109/24217

出版情報: 九州大学大学院農学研究院紀要. 42 (3/4)，pp.301-307，1998-03. Kyushu University バージョン：

権利関係 : 


\title{
Internode Elongation under Different Rising Water Conditions in African Floating Rice (Oryza glaberrima Steud.)
}

\author{
Maki Watarai and Jun Inouye \\ Laboratory of Crop Science, Faculty of Agriculture \\ Kyushu University, Fukuoka 812-8581, Japan \\ (Received October 30, 1997 and accepted December 3, 1997)
}

\begin{abstract}
The African and Asian floating rices were grown under different rising water conditions, and internode elongation ability with increasing water depth was measured. In $5 \mathrm{~cm} / 2$ daysubmerged lot, all varieties having LEI positions at the 8 th and 9 th internodes could grow until the end of the experiment along with the increase of the water depth in both species. In these varieties, differences between species in almost growth characters were not observed. Among varieties having LEI positions from the 10 th to 12 th internodes, one African and one Asian variety failed to grow. No varieties having LEI position at the 13 th internode could grow, because its average internode length was considerably short. Among varieties with LEI positions from the 8 th to 11 th internodes in $10 \mathrm{~cm} / 2$ day-submerged lot, 4 African varieties and one Asian variety did not grow. All varieties with LEI positions from the 12 th to 14 th internodes could not grow. From these results, it was suggested that under slow rising water conditions, internode elongation ability of both African and Asian floating rices was almost the same. Under rapid rising water conditions, however, internode elongation in the former was slightly inferior to that in the latter.
\end{abstract}

\section{INTRODUCTION}

Recently, in West African countries, rice cultivation areas are growing rapidly with an increase in the demand for rice (Nozaki 1989). However, the cultivation of African rice (Oryza glaberrima) is decreasing due to the introduction of Asian rice (O. sativa) $\mathrm{Ng}$ et al. 1991, Nsumbu 1991). African rice varieties are said to be adapted well to unfavourable environments such as drought at the early growth stage and sudden flooding, and they are currently cultivated mainly in the deep-water areas of West Africa (Coudhury and Will 1977, Katayama 1989, Oka et al. 1978).

In general, floating rice elongates with increasing water depth, while it shows a similar growth habit to ordinary paddy rice under shallow water conditions (Inouye and Hagiwara 1982, Oka 1988, Sugawara and Horikawa 1971). In Asian floating rice, the position of the lowest elongated internode (LEI) is quite stable. Floating rice internodes start to elongate upon reaching the growth stage peculiar to each variety (Inouye and Hagiwara 1981, Kiryu et al. 1995). Recently, on the other hand, it was revealed that the LEI position under non-submerged conditions was one to three internodes higher than that under submerged conditions in African floating rice (Watarai and Inouye 1997). This seems to show that African floating rice has a wider adaptability to various water conditions than Asian floating rice. It was reported that, among Asian varieties, the lower the LEI position, the better the elongation ability under rising water conditions (Ibi et al. 
1995, Inouye et al. 1985). The present study aims to compare the internode elongation between African and Asian floating rices under rising water conditions.

\section{MATERIALS AND METHODS}

\section{Experiment 1}

We used floating rice varieties obtained from previous experiments in which the position of the lowest elongated internode (LEI) was the 10 th internode under submerged conditions. The African group consisted of 7 Nigerian varieties, and the Asian group of 3 each of Indian and Thai, and 4 each of Bangladeshi, Cambodian and Vietnamese varieties.

About nine germinated seeds were sown at the end of May 1994 in a plastic pot $16 \mathrm{~cm}$ in diameter and $20 \mathrm{~cm}$ in height with a drainage hole in the bottom. Each pot contained about $3.5 \mathrm{~kg}$ of air-dried soil. Fertilizer was applied at the rate of $0.56 \mathrm{~g}$ each of $\mathrm{N}_{2} \mathrm{P}_{2} \mathrm{O}_{5}$, $\mathrm{K}_{3} \mathrm{O}$ per pot. At the 4 th leaf stage, seedlings were thinned to 3 plants per pot. Until the 9 th leaf stage, all pots were placed in a shallow water tank (water depth: about $10 \mathrm{~cm}$ ). In order to determine accurately the number of leaves on the main culm, small spots of enamel were applied as a marker on the leaf blades of every two leaves in each plant throughout the growing period. A few days before the rice plants of each variety reached the growth stage at which internode elongation can occur by submergence, the plants were submerged about $10 \mathrm{~cm}$. When internode elongation was observed in each pot, the pot was gradually submerged at the rate of $4 \mathrm{~cm}$ per day by being suspended with a string in the water tank. Water depth in the tank was about $280 \mathrm{~cm}$, of which about $150 \mathrm{~cm}$ was under the ground. Submerged treatments were terminated when about one-half of the expanded uppermost leaf blades of most culms in each pot were below water level or when the pot itself rested on the bottom of the tank. Average air temperature during the experiment ranged from 21 to $32^{\circ} \mathrm{C}$, and day length ranged from $12 \mathrm{hr} 50 \mathrm{~min}$ to $14 \mathrm{hr}$ $20 \mathrm{~min}$.

For our observations, the internodes whose length exceeded $0.5 \mathrm{~cm}$ were defined as the elongated internodes (Suetsugu 1968). The main culm was only subjected to investigation in which the datum of each variety was represented by the average value of two to three main culms. Before the onset of the submerging treatment, the LEI position and seedling height of each variety were recorded. At the end of the treatment, total plant length, number of leaves, number of elongated internodes, and the length of each internode were examined.

\section{Experiment 2}

Floating rice varieties from prior experiments were used. Their LEI position ranged from the 8 th to the 14 th internodes under submerged conditions. We used 13 African rice and 14 Asian rice varieties. The former consisted of 9 Nigerian and 4 Guinean varieties, and the latter of 3 each of Bangladeshi, Cambodian, Indian and Thai, and one each of the Myanmar and Vietnamese varieties.

Seeds were sown in a greenhouse at the end of May 1996 in same manner as in the experiment 1 . At the 6 th leaf stage, pots containing three plants were placed outdoor in a shallow water tank (water depth: about $5 \mathrm{~cm}$ ). The plants were submerged about $20 \mathrm{~cm}$ 
upon reaching the particular leaf stage at which internode elongation would occur for each variety. Each pot in which elongation was observed was gradually submerged at different rates of $5 \mathrm{~cm}$ and $10 \mathrm{~cm}$ every other day. The measuring procedure at the beginning and end of treatment were the same as in experiment 1. Average air temperature during the experimental period ranged from 20 to $31^{\circ} \mathrm{C}$, and day length from $11 \mathrm{hr} 40 \mathrm{~min}$ to $14 \mathrm{hr} 20 \mathrm{~min}$.

\section{RESULTS}

\section{Experiment 1}

In the preliminary experiment, the LEI position of all varieties used was the 10 th internode under shallow water conditions. In $4 \mathrm{~cm} /$ day-submerged lots, however, the LEI position was the 9 th internode in 2 Bangladeshi varieties and one Nigerian variety. The LEI position was the 10 th internode in all the others (Table 1). In this experiment, all the varieties were allowed to grow until the pot reached the bottom of the water tank, and the difference in growth between varieties with LEI positions at the 9 th and 10 th internodes in each rice species was not observed.

At the end of the experiment, in varieties with LEI position at the 10 th internode, the number of leaves on the main culm ranged from 21 to 23 in the Asian and from 20 to 22 in the African floating rice, an average $21.8 \pm 1.2$ and $20.8 \pm 0.8$ leaves, respectively. The plant length varied from $280 \mathrm{~cm}$ to $321 \mathrm{~cm}$ in the Asian and $243 \mathrm{~cm}$ to $301 \mathrm{~cm}$ in the African floating rices. The average length of the latter was shorter than that of the former by $27 \mathrm{~cm}$. The total internode length, which seems to have a close relation to the plant length, was from $194 \mathrm{~cm}$ to $255 \mathrm{~cm}$ in the Asian floating rice and from $179 \mathrm{~cm}$ to $224 \mathrm{~cm}$ in the African floating rice. The average length of the latter was shorter than that of the former by $19 \mathrm{~cm}$. The average internode length was almost the same in both groups. In 3 out of 7 African varieties used, the plant length was shorter by $20-40 \mathrm{~cm}$ than an Asian variety (Boyra) having poor elongation ability. The other 4 were almost similar to the Indian variety in plant length, the length of total elongated internodes, and the number of

Table 1. Comparison of some characteristics between $O$. sativa and $O$. glaberrima in $4 \mathrm{~cm} /$ daysubmerged lots.

\begin{tabular}{|c|c|c|c|c|c|c|c|c|c|}
\hline $\begin{array}{c}\text { LEI } \\
\text { Positions }\end{array}$ & Species & $\begin{array}{c}\text { Country of } \\
\text { origin }\end{array}$ & $\begin{array}{c}\text { No. of } \\
\text { var. }\end{array}$ & $\begin{array}{l}\text { Plant } \\
\text { length }\end{array}$ & $\begin{array}{l}\text { No. of } \\
\text { leaves }\end{array}$ & $\begin{array}{c}\text { No. of } \\
\text { elongated } \\
\text { internode }\end{array}$ & $\begin{array}{c}\text { Total } \\
\text { internode } \\
\text { length }\end{array}$ & $\begin{array}{c}\text { LEI } \\
\text { length }\end{array}$ & $\begin{array}{c}\text { Average } \\
\text { internode } \\
\text { length* }\end{array}$ \\
\hline \multirow[t]{2}{*}{9} & O. sativa & Bangladesh & 2 & $292 \pm 16$ & $19.5 \pm 0.7$ & $10.5 \pm 0.7$ & $218 \pm 9$ & $4.6 \pm 3.0$ & $21.2 \pm 3.8$ \\
\hline & O. glaberrima & Nigeria & 1 & 285 & 19 & 10.0 & 198 & 2.4 & 21.6 \\
\hline \multirow[t]{7}{*}{10} & O. sativa & Bangladesh & 2 & $291 \pm 16$ & $22.5 \pm 0.7$ & $12.5 \pm 0.7$ & $225 \pm 43$ & $4.4 \pm 2.7$ & $18.9 \pm 3.9$ \\
\hline & & Cambodia & 4 & $311 \pm 11$ & $21.0 \pm 0.0$ & $11.0 \pm 0.0$ & $231 \pm 11$ & $6.5 \pm 2.7$ & $22.3 \pm 1.5$ \\
\hline & & India & 3 & $288 \pm 8$ & $21.7 \pm 0.6$ & $11.7 \pm 0.6$ & $220 \pm 5$ & $9.2 \pm 2.1$ & $20.3 \pm 0.4$ \\
\hline & & Thailand & 3 & $316 \pm 1$ & $22.0 \pm 0.0$ & $12.0 \pm 0.0$ & $231 \pm 7$ & $3.0 \pm 1.9$ & $20.3 \pm 1.3$ \\
\hline & & Vietnam & 4 & $307 \pm 7$ & $22.0 \pm 1.2$ & $12.0 \pm 1.2$ & $213 \pm 7$ & $5.3 \pm 3.3$ & $19.2 \pm 1.8$ \\
\hline & & Total & 16 & $304 \pm 14$ & $21.8 \pm 1.2$ & $11.8 \pm 0.8$ & $223 \pm 15$ & $5.8 \pm 3.1$ & $20.2 \pm 1.2$ \\
\hline & O. glaberrima & Nigeria & 6 & $275 \pm 22$ & $20.8 \pm 0.8$ & $10.8 \pm 0.8$ & $204 \pm 18$ & $4.9 \pm 2.3$ & $19.9 \pm 1.2$ \\
\hline
\end{tabular}

* Average length of all elongated internodes expecting the youngest internode. 
elongated internodes.

\section{Experiment 2}

In $5 \mathrm{~cm} / 2$ day-submerged lots, all the varieties in which the LEI position was at the 8 th and the 9 th internodes we allowed to grow until the pot reached the bottom of the tank (Table 2(a)). The variation in most growth characters in the African was smaller than that in the Asian floating rice, whereas the average value was nearly the same in both.

Each one variety of African and Asian floating rice with LEI positions at the 10 th and the 11 th internodes did not grow until the end of the treatment. In varieties which did grow, the average value of most growth characters was the same in both groups. In the Asian group, the variation in plant length among varieties paralleled that in total internode length, whereas, in the African group, the internode length variation among varieties was larger than that of plant length. In varieties which failed to grow among

Table 2. Comparison of some characteristics between $O$. sativa and $O$. glaberrima in submerged lots.

(a): $5 \mathrm{~cm} / 2$ days

\begin{tabular}{clcccccccc}
\hline $\begin{array}{c}\text { LEI } \\
\text { position }\end{array}$ & \multicolumn{1}{c}{ Species } & No. of var. $\begin{array}{c}\text { Plant } \\
\text { length }\end{array}$ & $\begin{array}{c}\text { No. of } \\
\text { leaves }\end{array}$ & $\begin{array}{c}\text { No. of } \\
\text { elongated } \\
\text { internodes }\end{array}$ & $\begin{array}{c}\text { Total } \\
\text { internode } \\
\text { length }\end{array}$ & $\begin{array}{c}\text { LEI } \\
\text { length }\end{array}$ & $\begin{array}{c}\text { Average } \\
\text { internode } \\
\text { length** }\end{array}$ \\
\hline 89 & O. sativa & 7 & 7 & $294 \pm 11$ & $21.3 \pm 1.4$ & $12.4 \pm 1.5$ & $214 \pm 10$ & $9.4 \pm 5.0$ & $18.5 \pm 1.6$ \\
\cline { 2 - 10 } & O.glaberrima & 4 & 4 & $282 \pm 12$ & $21.0 \pm 0.0$ & $12.0 \pm 0.0$ & $214 \pm 4$ & $6.0 \pm 2.4$ & $17.5 \pm 0.4$ \\
\hline \multirow{2}{*}{$10-11$} & O. sativa & 4 & 3 & $292 \pm 13$ & $22.7 \pm 1.5$ & $12.3 \pm 1.2$ & $203 \pm 4$ & $7.2 \pm 0.4$ & $17.4 \pm 2.0$ \\
& & & $1^{*}$ & 237 & 20 & 10 & 154 & 5.6 & 15.1 \\
\hline & O. glaberrima & 5 & 4 & $279 \pm 15$ & $22.0 \pm 0.8$ & $11.7 \pm 0.6$ & $198 \pm 36$ & $9.3 \pm 3.7$ & $17.6 \pm 2.4$ \\
\hline 12 & O. sativa & 1 & 1 & 290 & 23 & 11 & 211 & 7.6 & 19 \\
\hline 13 & O. sativa & 2 & $2^{*}$ & $139 \pm 9$ & $19.0 \pm 0.0$ & $6.0 \pm 0.0$ & $58 \pm 2$ & $3.0 \pm 1.5$ & $9.1 \pm 1.0$ \\
\cline { 2 - 9 } & O.glaberrima & 4 & $4^{*}$ & $156 \pm 25$ & $20.3 \pm 3.0$ & $7.5 \pm 3.1$ & $95 \pm 45$ & $3.8 \pm 2.3$ & $12.6 \pm 2.7$ \\
\hline
\end{tabular}

(b) $10 \mathrm{~cm} / 2$ days

\begin{tabular}{|c|c|c|c|c|c|c|c|c|c|}
\hline $\begin{array}{c}\text { LEI } \\
\text { position }\end{array}$ & Species & No. of & var. & $\begin{array}{l}\text { Plant } \\
\text { length }\end{array}$ & $\begin{array}{l}\text { No. of } \\
\text { leaves }\end{array}$ & $\begin{array}{c}\text { No. of } \\
\text { elongated } \\
\text { internodes }\end{array}$ & $\begin{array}{c}\text { Total } \\
\text { internode } \\
\text { length }\end{array}$ & $\begin{array}{c}\text { LEI } \\
\text { length }\end{array}$ & $\begin{array}{c}\text { Average } \\
\text { internode } \\
\text { length** }\end{array}$ \\
\hline \multirow[t]{3}{*}{$8-9$} & O. sa & 7 & 7 & 278 & 18.0 & $9.1 \pm 1.6$ & $212 \pm 13$ & 12.9 & $23.5 \pm 2.8$ \\
\hline & O. glaberr & 4 & 2 & $271 \pm 2$ & $17.5=$ & $8.5 \pm 0.7$ & $200 \pm 8$ & $21.6=$ & 24.3 \\
\hline & & & $2^{*}$ & $203 \pm 1$ & $15.0 \pm 0.0$ & $6.5 \pm 0.7$ & $133 \pm 8$ & $11.6 \pm$ & 21.7 \\
\hline \multirow[t]{4}{*}{$10-11$} & O. $s$ & 4 & 3 & $277 \pm 25$ & $16.3 \pm 0.6$ & $6.7 \pm 1.2$ & $185 \pm 28$ & $9.3 \pm 4.4$ & $27.4 \pm 4.5$ \\
\hline & & & $1^{*}$ & & & 3 & 47 & 8 & \\
\hline & O. glaberrima & 4 & 2 & $262 \pm 16$ & $17.5 \pm 0.7$ & $8.0 \pm 0.0$ & $197 \pm 17$ & $19.5 \pm 5.9$ & $27.5 \pm 1.9$ \\
\hline & & & $2^{*}$ & $144 \pm 27$ & $15.5 \pm 0.7$ & $4.5 \pm 0.7$ & $65 \pm 37$ & $8.0 \pm 2.4$ & $15.5 \pm 5.1$ \\
\hline \multirow[t]{2}{*}{$12-14$} & O. sativa & 3 & $3^{*}$ & $122 \pm 67$ & $15.5 \pm 0.6$ & $3.7 \pm 1.2$ & $48 \pm 59$ & $5.9 \pm 7.4$ & $11.3 \pm 10.5$ \\
\hline & O. glaberrima & 5 & $5^{*}$ & $123 \pm 18$ & $16.4 \pm 2.3$ & $3.8 \pm 2.2$ & $43 \pm 24$ & $4.8 \pm 1.3$ & $10.9 \pm 3.4$ \\
\hline
\end{tabular}

* Number of the varieties which could not grow until the end of the submerging treatment.

** Average length of all elongated internodes excepting the youngest internode. 
Asian floating rices, the average internode length was shorter than in the other varieties. However, in the African floating rice, the leaf emergence rate was slightly late, and the length of the leaf blade and leaf sheath were short, although there was no difference in average internode length. The characters of an Asian variety with LEI position at the 12 th internode were quite similar to the floating rice varieties with LEI positions at the 8 th and the 9 th internodes. The floating rice varieties with LEI positions at the 13 th internode failed to grow, and the average internode length was short. Further, the average value of almost all characters in the African group was superior to that in the Asian, but the variation among varieties in the former was larger than that in the latter.

In $10 \mathrm{~cm} / 2$ day-submerged lots, all Asian floating rice varieties with LEI positions at the 8 th and the 9 th internodes grew until the end of the treatments, while 2 out of 4 African varieties did not (Table $2(\mathrm{~b})$ ). In varieties which grew, the average internode length was almost the same in both groups, although the total internode length in the African group was slightly shorter than that in the Asian. In 2 African floating rice varieties which did not grow, the average internode length was shorter than that in the others by $2.6 \mathrm{~cm}$. In floating rice varieties with LEI positions at the 10 th and the 11 th internodes, 2 out of 4 African varieties and one out of 4 Asian varieties failed to grow. Among varieties which did grow, the total internode length of the African rice was longer than that of the Asian rice. The average internode length was nearly the same in both groups, although the plant length in the former was shorter than that in the latter. In varieties which did not grow, however, the average internode length was a half that of varieties that did. No varieties with LEI positions at the 12 th to the 14 th internodes grew. In both groups, the average internode length was short. In addition, in the average value of all characters, the difference between species was not observed, however, the variation among varieties in plant length and total internode length was much greater among the Asian than among the African varieties.

\section{DISCUSSION}

In African floating rice, internodes elongates with increasing water depth when they reach the lag phase. This phenomenon is the same as in the Asian floating rice. In the latter, the start of internode elongation, i.e., the position of the lowest elongated internode (LEI), is thought to be almost constant regardless of water conditions and to be quite stable in its morphological characteristics (Inouye and Hagiwara 1981, Kiryu et al. 1995). However, in African floating rice, the LEI position under non-submerged conditions was higher than that under submerged conditions. This suggests that the African varieties can start internode elongation to coincide with the arrival of flooding (Watarai and Inouye 1997). In floating rice, internode elongation ability with increasing water depth and the size of total internode length were essential characteristics of floating ability, and were as important as start of internode elongation. In this experiment, the African and Asian varieties were grown under different rising-water conditions.

When varieties with LEI position of the 10 th internode were grown under $4 \mathrm{~cm} /$ daysubmerged conditions, plant length and total internode length in the African varieties were shorter than those in the Asian. This was because the leaf emergence rate under the rising water conditions in the African group was slower. Therefore, number of leaves 
in the African group were fewer as well as number of elongated internode. Considering that the leaf emergence rate is influenced by climate (Sato 1972, Takamura et al. 1961), the temperature during the experiment may be slightly low for African floating rice. However, the effect of submergence on the leaf emergence rate was not obvious. Further, the average internode length was almost the same in both groups.

In $5 \mathrm{~cm} / 2$ day-submerged lots, among 21 varieties having LEI positions from the 8 th to the 12 th internodes, one African and one Asian variety failed to grow until the end of the experiment. In floating rice varieties which grew, differences between species in plant length, total internode length and average internode length were not observed. No varieties with LEI positions at the 13 th internode could grow. This seems the reason why the average internode length was considerably short. Generally, in the Asian varieties, the lower the LEI position, better the internode elongation ability. In this experiment, the African group seemed to be the same as the Asian in so far as varieties with a low LEI position could grow until the end of the experiment.

Among varieties with LEI positions from the 8 th to 11 th internodes in $10 \mathrm{~cm} / 2$ daysubmerged lots, one Asian variety with LEI position at the 10 th internode and each of 2 African varieties with LEI positions at the 9 th and the 11 th internodes did not grow. Among plants which did grow, although the plant length in the African varieties was slightly shorter than that in the Asian, the difference between species in total internode length was not obvious, and the average internode length was almost the same in the both groups. All floating rice varieties with LEI positions from the 12 th to 14 th internodes did not grow. This was because the average internode length was rather short. According to Ibi et al. (1995), Asian floating rice was grown in $4 \mathrm{~cm} /$ day-submerged lots; consequently, in varieties with LEI positions at the 12 th and 13 th internodes, the increase in water depth by $4 \mathrm{~cm}$ per day seemed to be the limitation for their elongation ability. In this experiment, no varieties with LEI positions from the 12 th to 14 th internodes could grow in $10 \mathrm{~cm} / 2$ day-submerged lots, and no difference between the African and Asian varieties was observed.

From the above, we conclude that under slow rising water conditions as in $5 \mathrm{~cm} / 2$ day-submerged lots, the internode elongation ability of both African and Asian floating rices was almost the same in that the leaf age of the start of internode elongation was the same in both. Under rapid water rising conditions such as $4 \mathrm{~cm} /$ day- and $10 \mathrm{~cm} / 2$ daysubmerged lots, however, it was suggested that internode elongation in the former was slightly inferior to that in the latter.

However, it was reported that the variation in water depth in African flooding areas was more serious than in Asia, with fluctuations of more than $10 \mathrm{~cm}$ (Katayama 1989). In addition, there were some reports that African floating rice was more tolerant to unfavourable conditions such as flooding than Asian floating rice (Coudhury and Will 1977, Oka et al. 1978). Therefore, information about the internode elongation of African floating rice in such a challenging environment is always important and deserving of further study.

\section{ACKNOWLEDGEMENTS}

The authors greatly appreciate to Tomohiko Yoshida, associate professor, Faculty of 
Agriculture, Kyushu University, for his valuable suggestions.

\section{REFERENCES}

Coudhury, M. A. and H. Will 1977 Progress in deep-water rice research in West Africa. In "Proc. 1976 Intl. Deep-water Rice Workshop", IRRI, Los Banos, pp. 167-175

Ibi, A., T. Mochizuki and J. Inouye 1995 On the relation between position of the lowest elongated internode (LEI) and elongation ability of internodes under rising water conditions in Asian deepwater rice, Oryza sativa L. Jpn. J. Trop. Agr., 39: 76-81

Inouye, J. 1983 Relation between elongation ability and internode elongation of floating rice under rising water conditions. Jpn. J. Trop. Agr., 27: 181-186

Inouye, J. and T. Hagiwara 1981 Effects of some environmental factors on the position of the lowest. elongated internode of three floating rice varieties. Jpn. J. Trop. Agr., 25: 115-121

Inouye, J. and T. Hagiwara 1982 Difference of morphological plant growth between submerged and nonsubmerged conditions in a floating rice variety. Jpn. J. Trop. Agr., 26: 14-18

Inouyc, J., D. H. R. Lambers and S. Chitrakon 1985 Some morphological and ecological differences between floating and non-floating rice varieties in Thai paddy rice, Oryza sativa L.. Bull. Inst. Trop. Agr. Kyushu Univ, 8: $55-89$

Katayama, T. C. 1989 Current status of African rice culture-mainly, from the technological aspect-. Intl. Coop. Agric. For., 12: 2-12

Kiryu, S, K. Takahashi and K. Hoshikawa 1995 Phase change of stem development during vegetative stage in deepwater rice. Jpn. J. Crop Sci, 64 (Extra issue 1): 134-135

Nozaki, M. 1989 Rice culture in West Africa. Intl. Coop. Agric. For., 12: 13-31

Ng, N. Q., T. T. Chang, D. A. Vaughan and C. Z. -A. Veros 1991 African rice diversity: Conservation and prospects for crop improvement. Crop Genet. Resources Africa II Proc. Int1. Conf. Crop Genet. Resources Africa, IITA, Ibadan, Nigeria, : 213-227

Nsumbu,N. 1991 Keynote Address. Crop Genet. Resources Africa I Proc. Intl. Conf. Crop Genet. Resources Africa, IITA, Nairobi, Kenya, : 35-41

Oka, H. I. 1988 Origin of cultivated rice. Japan Scientific Societies Press, Tokyo and Elsevier Science publishers, Amsterdam, pp. 216.

Oka, H. I., H. Morishima, Y. Sano and T. Koizumi 1978 Observations of rice species and accompanying savanna plants on the southern fringe of Sahara Desert (Report of study-tour in West Africa, 1977). Natl. Inst. Genet., Mishima, Japan, pp. 94

Sato, K. 1972 Growth responses of rice plant to environmental conditions I The effects of airtemperatures on the growth at vegetative stage. Proc. Crop Sci. Soc. Japan, 42: 388-393

Suetsugu, 1. 1968 Studies on the first jointing stage in rice plants -Morphogenetic phases of stem development in rice shoots-. Proc. Crop Sci. Soc. Japan, 37: 489-498

Sugawara, T. and T. Horikawa 1971 Studies on the elongation of internodes in floating rice plantsMorphological and histological observation-. Bull. Col. Agr. Utsunomiza Univ., 8: 25-46

Takamura, Y., S. Takeuchi and H. Hasegawa 1961 Studies on the effects of soil temperature upon the growth of crop plants (III) Soil temperature and leaf emergence of rice plant. (VII) Relation of temperature of several parts of rice plant to the rate of leaf emergence. Proc. Crop Sci. Soc. Japan, 29: $195-198$

Watarai, M. and J. Inouye 1997 Effect of water conditions on the LEI position of African floating rice (Oryza glaberrima Steud.). Jpn. J. Crop. Sci., 66: $300-306$ 